\title{
Hematology and Serum Biochemistry of the Egyptian Mongoose, Herpestes ichneumon
}

F. Palomares,' M. Delibes,' and F. Recio,'2 'Estación Biológica Doñana, CSIC, Apdo. 1056, 41080 Sevilla, Spain; ${ }^{2}$ Hospital Universitario de Valme, Servicio Andaluz de Salud, Ctra. Cádiz, s/n, 41014 Sevilla, Spain

ABSTRACT: Hematology and serum biochemical data are presented for the Egyptian mongoose, Herpestes ichneumon, caught in Doñana National Park, southwestern Spain.

Key words: Egyptian mongoose, Herpestes ichneumon, hematology, serum biochemistry.

There has been increasing interest in the hematology and serum biochemistry of mammals, particularly carnivores (Seal et al., 1975; Brannon, 1985a, b; Caro et al., 1987; Beltrán et al., 1991). However, there are few studies of free-ranging carnivores. We present the first hematologic and serum biochemical data from free-ranging Egyptian mongooses (Herpestes ichneumon), a species living in southwestern Europe (Delibes, 1982).

The study was carried out at Donana National Park, southwestern Spain $\left(37^{\circ} 9^{\prime} \mathrm{N}\right.$, $6^{\circ} 26^{\prime} \mathrm{W}$ ), a flat region on the west bank of the Guadalquivir River mouth, encompassing three major biotopes: marsh, dunes and matorral (Rogers and Myers, 1980).

Blood samples were collected and analyzed in December $1985(n=1)$, March to May $1989(n=5)$, and in July $1989(n$ $=2$ ). Six mongooses (four adult females, one adult male, and one $<1-y r$-old female were captured with baited box-traps, which were checked daily. Another adult male was captured by excavating an underground den, just after it fought with an Iberian lynx, Felis pardina. Age on all animals was determined from body weight and dentition wear (Palomares and Delibes, 1992). After capture, each mongoose was transported to the laboratory and immobilized with a combination of $4.2 \mathrm{mg} / \mathrm{kg}$ of body weight of ketamine hydrochloride (Ketolar, Parke-Davis, Barcelona, Spain) and $6.5 \mathrm{mg} / \mathrm{kg}$ of xylazine hydrochloride (Rompum, Bayer, Barcelona, Spain). Mean induction time was 7 $\min (\mathrm{SD}=3.7)$. One to $3 \mathrm{ml}$ of blood were taken from the radial or femoral vein 20 to $35 \mathrm{~min}$ after induction. In two cases, the blood volume was insufficient for both hematological and serum biochemical analyses in an animal; thus, only six animals were considered for each analysis. One adult female (H110) was sampled twice: once upon capture and again after being in captivity for 12 days. This female was visibly pregnant during the first sample, but had lost the fetus when sampled later.

Blood samples were collected in tubes containing tripotassium ethylene diamine tetraacetic acid for cellular counts, and into plain serum tubes for biochemical analyses. Blood samples were stored at $4 \mathrm{C}$. All analyses were conducted within $24 \mathrm{hr}$ of collection. Plasma was collected from whole blood centrifuged for $10 \mathrm{~min}$ at 3,000 g. Blood was analyzed at the Valme University Hospital (Seville, Spain) using a Coulter S Plus II (Izasa, Barcelona, Spain) to determine 15 hematological characteristics. A Hitachi 717 autoanalyzer (Boehringer Mannheim, Barcelona, Spain) and a Beckman Electrolyte Model 4 (Beckman, Madrid, Spain) were used to measure concentration of 23 serum characteristics by the methods of García-Rodriguez et al. (1987).

The results are summarized in Tables 1 and 2. For female $\mathrm{H} 110$, values for hemoglobin, mean corpuscular hemoglobin, mean corpuscular hemoglobin concentration, erythrocyte distribution, platelet volume, and granulocyte percentage were lower during pregnancy than after, whereas values for erythrocytes, packed cell volume, mean corpuscular volume and monocytes percentage were lower after the termination of pregnancy (Table 1). Val- 
TABLE 1. Hematological values for five Egyptian mongooses, and an adult female (H110) sampled two times, Doñana National Park, Spain, 1985 to 1989

\begin{tabular}{|c|c|c|c|c|c|}
\hline & \multirow{2}{*}{$\begin{array}{c}\text { Mean } \\
(n=5)\end{array}$} & \multirow[b]{2}{*}{ SD } & \multirow[b]{2}{*}{ Range } & \multicolumn{2}{|c|}{$\mathrm{H} 110$} \\
\hline & & & & $\mathrm{A}^{*}$ & $\mathrm{~B}^{*}$ \\
\hline \multicolumn{6}{|c|}{ Hematological parameters } \\
\hline Leukocytes $\left(10^{3} / \mu \mathrm{l}\right)$ & 13.9 & 4.0 & 10.0 to 20.5 & 15.6 & 6.7 \\
\hline Erythrocytes $\left(10^{6} / \mu \mathrm{l}\right)$ & 8.6 & 0.7 & 7.6 to 9.7 & 9.1 & 8.1 \\
\hline Hemoglobin $(\mathrm{g} / \mathrm{dl})$ & 14.9 & 1.0 & 14.1 to 16.1 & 13.4 & 13.8 \\
\hline Packed cell volume $(\%)$ & 41.7 & 4.3 & 37.0 to 47.3 & 47.1 & 39.1 \\
\hline Mean corpuscular volume (fl) & 48.3 & 0.6 & 47.7 to 49.0 & 51.8 & 48.0 \\
\hline Mean corpuscular hemoglobin (pg) & 17.4 & 0.9 & 16.6 to 18.8 & 14.7 & 17.0 \\
\hline Mean corpuscular hemoglobin concentration $(\mathrm{g} / \mathrm{dl})$ & 35.8 & 1.8 & 34.0 to 38.5 & 28.5 & 35.3 \\
\hline Erythrocyte distribution (\%) & 28.6 & 10.0 & 17.4 to 39.9 & 15.7 & 19.9 \\
\hline Platelet count $\left(10^{12} / \mathrm{l}\right)$ & 533.8 & 123.9 & 384 to 649 & 567 & 375 \\
\hline Packed platelet volume $(\mathfrak{f})$ & 11.0 & 1.6 & 9.8 to 13.8 & 6.9 & 10.5 \\
\hline \multicolumn{6}{|c|}{ Leukocyte Differential Count (\%) } \\
\hline Lymphocytes & 14.0 & 3.8 & 10 to 18 & 5 & 9 \\
\hline Monocytes & 5.0 & & & 10 & 4 \\
\hline Granulocytes & 81.2 & 1.2 & 4 to 7 & 65 & 87 \\
\hline Eosinophils & 0 & 4.4 & 78 to 87 & 0 & 0 \\
\hline Basophils & 0 & & & 0.3 & 0 \\
\hline
\end{tabular}

-A, Sample at time of capture when female was pregnant; B, sample 12 days after capture when the fetus was lost.

TABLE 2. Mean serum biochemical values for five Egyptian mongooses and an adult female (H110) sampled two times, Doñana National Park, Spain, 1985 to 1989.

\begin{tabular}{|c|c|c|c|c|c|c|}
\hline \multirow[b]{2}{*}{ Biochemical parameters } & \multirow{2}{*}{$\begin{array}{l}\text { Num- } \\
\text { ber of } \\
\text { mon- } \\
\text { gooses }\end{array}$} & \multirow[b]{2}{*}{ Mean } & \multirow[b]{2}{*}{ SD } & \multirow[b]{2}{*}{ Range } & \multicolumn{2}{|c|}{ H110 } \\
\hline & & & & & $\mathbf{A}^{*}$ & B. \\
\hline Glucose (mg/dl) & 5 & 174.6 & 51.7 & $119-259$ & 213 & 157 \\
\hline Urea $(\mathrm{mg} / \mathrm{dl})$ & 5 & 57.4 & 17.1 & $35-71$ & 71 & 59 \\
\hline Creatinine $(\mathrm{mg} / \mathrm{dl})$ & 5 & 0.8 & 0.2 & $0.6-1.0$ & 0.9 & 0.9 \\
\hline Uric acid (mg/dl) & 5 & 1.0 & 0.6 & $0.4-2.0$ & 0.6 & 1.1 \\
\hline Calcium (mg/l) & 4 & 10.5 & 0.5 & $10-11$ & 9.8 & 10.9 \\
\hline Phosphorus (mg/dl) & 5 & 5.7 & 0.6 & $4.8-6.5$ & 4.4 & 5.6 \\
\hline Total proteins $(\mathrm{g} / \mathrm{dl})$ & 4 & 7.9 & 0.5 & $7.2-8.4$ & 7.1 & 8.3 \\
\hline Total bilirubin $(\mathrm{mg} / \mathrm{dl})$ & 4 & 0.2 & 0.1 & $0.1-0.3$ & 0.2 & 0.2 \\
\hline Glutamic-oxalacetic transaminase $(\mu / \mathrm{l})$ & 5 & 195.8 & 64.7 & $153-301$ & 90 & 110 \\
\hline Glutamic-pyruvic transaminase $(\mu / \mathrm{l})$ & 5 & 162.8 & 61.5 & $104-246$ & 97 & 155 \\
\hline Alkaline phosphatase $(\mathrm{i} \mu / \mathrm{l})$ & 4 & 340.5 & 92.7 & $241-449$ & 136 & 226 \\
\hline Colinesterase $(\mu / \mathrm{l})$ & 5 & $1,052.8$ & 349.4 & $665-1,259$ & 1,001 & 1,769 \\
\hline Gamma glutamil transpeptidase $(\mu / \mathbf{l})$ & 4 & 2.8 & 1.0 & $2-4$ & 1 & 1 \\
\hline Creatine phosphokinase $(\mu / \mathrm{l})$ & 4 & 478.3 & 269.0 & $166-815$ & 122 & 279 \\
\hline Lactatedehydrogenase $(\mu / \mathrm{l})$ & 4 & 2,243 & 518.9 & $1,486-2,586$ & 1,056 & 1,411 \\
\hline Amylase $(\mu / \mathrm{l})$ & 4 & 2,461 & $1,638.9$ & $117-3,607$ & 2,941 & 4,858 \\
\hline Cholesterol (mg/dl) & 4 & 260.5 & 100.7 & $180-405$ & 286 & 278 \\
\hline Triglycerides $(\mathrm{mg} / \mathrm{dl})$ & 4 & 18.8 & 16.3 & $6-42$ & 2 & 13 \\
\hline Magnesium (mg/dl) & 3 & 2.4 & 0.3 & $2.2-2.4$ & 1.8 & 2.3 \\
\hline Sodium (meq/l) & 4 & 150 & 13.1 & $131-161$ & 149 & \\
\hline Potassium (meq/l) & 4 & 4.4 & 0.4 & $3.9-4.7$ & 5.3 & \\
\hline Chloride (meq/l) & 1 & 129 & & & 112 & \\
\hline Indirect bilirubin $(\mathrm{mg} / \mathrm{dl})$ & 3 & 1.1 & 1.1 & $0.3-2.4$ & 0.2 & 0.3 \\
\hline
\end{tabular}

- A, Sample at time of capture when female was pregnant; B, sample 12 days after capture, when the fetus was lost. 
ues of many serum characteristics during female H110's pregnancy also differed from the other mongooses (Table 2).

This research was supported by DGICYT (project PB87-0405). One of us (FP) has a postdoctoral grant of Consejo Superior de Investigaciones Científicas. We thank Dr. J. F. Beltrán for his assistance and guidance during the blood sample extractions, and two anonymous referees for helpful comments on the original manuscript. Many people at the Department of Hematology, and at the Laboratory of Biochemistry of Hospital Universitario de Valme helped with the analyses. N. Bustamante reviewed the English version.

\section{LITERATURE CITED}

Beltrán, J. F., M. Delibes, F. Recio, and C. Aza. 1991. Hematological and serum chemical characteristics of the Iberian lynx (Lynx pardina) in southwestern Spain. Canadian Journal of Zoology 69: 840-846.

BranNon, R. D. 1985a. Hematological characteristics of grizzly bears (Ursos arctos) in central and northeastern Alaska. Canadian Journal of Zoology 63: 58-62.
- 1985b. Serum chemistry of central and northern Alaska grizzly bears. The Journal of Wildlife Management 49: 893-900.

Caro, T. M., M. E. Holt, C. D. Fitzgibbon, M. BuSH, C. M. HaWkeY, and R. A. KoCK. 1987. Health of adult free-living cheetahs. Journal of Zoology, London 212: 573-584.

Delibes, M. 1982. Notas sobre la distribución pasada y actual del meloncillo Herpestes ichneumon (L.) en la Peninsula Ibérica. Doñana Acta Vertebrata 9: 341-352.

Garcia-Rodriguez, T, M. Ferrer, F. Recio, and J. Castroviejo. 1987. Circadian rhythms of determined blood chemistry values in buzzards and eagle owls. Comparative Biochemistry and Physiology 88A: 663-669.

Palomares, F., AND M. Delibes. 1992. Some physical and population characteristics of Egyptian mongooses Herpestes ichneumon (L., 1758) in southwestern Spain. Zeitschrift für Säugetierkunde 57: 94-99.

Rogers, P. M., AND K. Myers. 1980. Animal distributions, landscape classification and wildlife management, Coto Doñana, Spain. Journal of Applied Ecology 17: 545-565.

Seal, U. S., L. D. Mech, and V. Van BalLENBERGHE. 1975. Blood analyses of wolf pups and their ecological and metabolic interpretation. Journal of Mammalogy 56: 64-75.

Received for publication 5 September 1991. 